\title{
The real-world efficacy and safety of direct-acting oral antiviral treatment in chronic Hepatitis C Genotype 1 patients in Turkey
}

\section{Türkiye"de kronilk Hepatit C Genotip 1 hastalarında direkt-etkili oral antiviral tedavinin gerçek yaşamda etkinliği ve güvenliği}

Erol Cakmak

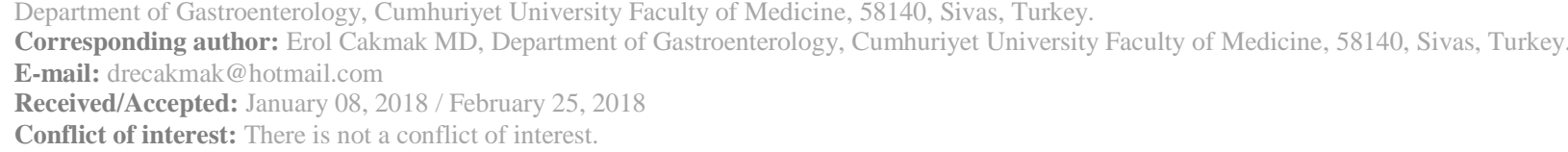

Objective: The aim of this study was to investigate the real-world efficacy and safety in Turkey of the paritaprevir/ritonavir, ombitasvir, dasabuvir (PrOD) \pm ribavirin $(\mathrm{RBV})$ and ledipasvir/sofosbuvir $(\mathrm{LDV} / \mathrm{SOF}) \pm \mathrm{RBV}$ combination regimens used for chronic hepatits $\mathrm{C}$ virus $(\mathrm{HCV})$ genotype 1 patients, which is the most common form of this disease seen both in Turkey and worldwide.

Method: The study included a total of $81 \mathrm{HCV}$ genotype 1 patients receiving $\mathrm{PrOD} \pm \mathrm{RBV}$ or LDV/SOF $\pm \mathrm{RBV}$ treatment regimens between June 2016 and October 2017. The patients were evaluated in respect of demographic, clinical and virological data, sustained virologic response (SVR) and detailed adverse events (AE).

Results: The $81 \mathrm{HCV}$ patients comprised 35 (43.2\%) males and $46(56.8 \%)$ females with a mean age of 62 years. All the patients were genotype 1 , which is the most commonly seen genotype in Turkey, and the sub-genotypes were HCV genotype $1 \mathrm{a}$ in $12.3 \%$ and genotype $1 \mathrm{~b}$ in $87.7 \%$. The SVR12 rate of all the chronic HCV genotype 1 patients was 79 (96.4\%), 98.2\% in the PrOD \pm RBV patients and 96\% in SOF/LDV \pm RBV. AEs were reported in 46 (56.8\%) of the total patient group. The most common AEs were pruritus in $18(22.2 \%)$ patients, fatigue in $17(21 \%)$ and headache in 16 $(19.8 \%)$.

Conclusions: According to the real-world data obtained in this study from a single centre in our region, a high rate of SVR12 response was obtained direct-acting oral viral treatment regimens in patients with chronic HCV genotype 1 and there was seen to be excellent tolerability.

Keywords: Antiviral agents, Hepatitis C chronic, safety, sustained virologic response.

ÖZET

Amaç: Bu çalışmanın amacı, Türkiye'de ve dünyada kronik hepatit C virüsünün (HCV) en yaygın şekli olan genotip 1 hastalarında kullanılan paritaprevir / ritonavir, ombitasvir, dasabuvir (PrOD) \pm ribavirin (RBV) ve ledipasvir / sofosbuvir (LDV / SOF) \pm RBV kombinasyon rejimlerinin gerçek yaşamda etkinliğini ve güvenirliğini araştırmakdı.

Yöntem: Haziran 2016 ile Ekim 2017 yılları arasında, PrOD \pm RBV veya LDV / SOF \pm RBV tedavi rejimleri alan toplam $81 \mathrm{HCV}$ genotipi 1 hasta dahil edildi. Hastalar demografik, klinik ve virolojik verileri, kalıcı virolojik yanıt (KVY) ve ayrıntılı yan etkiler değerlendirildi.

Bulgular: 81 HCV hastası, 35 (\% 43.2) erkek, 46 (\% 56.8) kadın olup ortalama yaş 62 idi. Hastalar Türkiye'de en s1k görülen genotip olan genotip 1 ve alt genotipler \% 12.3 genotip 1a ve \% 87.7 genotip 1 b idi. Kronik HCV genotip 1 hastalarının KVY oranı 79 (\% 96.4), PrOD \pm RBV hastalarında \% 98.2 ve SOF / LDV \pm RBV'de \% 96 idi. Ayrıntılı yan etki 46 (\% 56.8) hastada bildirildi. Hastalarda en sık görülen yan etkiler; 18 (\% 22.2) kaşıntı, 17 yorgunluk (\% 21) ve 16 (\% 19.8) baș ağrısı idi.

Sonuç: Bu çalışmada bölgemizdeki tek bir merkezden elde edilen gerçek yaşam verilerine göre, kronik HCV genotip 1 hastalarında direkt etkili oral viral tedavi rejimleri ile yüksek KVY 12 yanıtı elde edildi ve mükemmel tolere edildiği görüldü.

Anahtar sözcükler: Antiviral ajanlar, Hepatitis C kronik, güvenlik, kalıc1 viral yanıt. 


\section{INTRODUCTION}

Chronic hepatitis $\mathrm{C}$ virus (HCV) infection causes progressive liver disease including cirrhosis and hepatocellular carcinoma and is a primary indication for liver transplantation ${ }^{1}$. In the study of the World Health Organization (WHO), it was estimated that $1.1 \%$ of the global population and approximately 80 million individuals have viremic $\mathrm{HCV}$ infection. The prevalence of this infection shows geographical differences and very few people are aware of the disease ${ }^{2}$. In Turkey, it is estimated that the prevalence of chronic $\mathrm{HCV}$ infection is $1 \%$ and approximately 800,000 individuals have the virus ${ }^{3}$. Both worldwide and in Turkey, the most common HCV genotype is genotype 1 with a prevalence of $91.8 \%{ }^{4,5}$.

Successful eradication of HCV infection reduces complications which develop associated with $\mathrm{HCV}$, liver transplantation and the mortality risk ${ }^{6}$. With interferon (IFN)-based treatment in chronic HCV genotype 1 patients, the sustained virologic response (SVR) rate is $40 \%-50 \%$, there are greater side-effects related to the treatment and the treatment-dependence rate is extremely low ${ }^{7,8}$. In recent years, with the use of second-generation direct-acting antiviral agents (DAA) without interferon, SVR12 rates in genotype 1 patients have been reported to be $>90 \%$ and treatmentdependence rates have increased ${ }^{8}$. One of these new combined regimens is formed of paritaprevir/ritonavir, ombitasvir, dasabuvir (PrOD); paritaprevir (NS3/4A protease inhibitor), ritonavir (cytochrome $\mathrm{P} 450$ inhibitor), ombitasvir (NS5A inhibitor) and dasabuvir (NS5B polymerase inhibitor). In real-world data, this combined regimen of PrOD, with or without ribavirin (RBV) has been reported to obtain SVR12 rates of 94\%$100 \%$ in treatment-naive and treatmentexperienced genotype 1 patients with and without cirrhosis ${ }^{9}$. Another regimen of ledipasvir (NS5A inhibitor) and sofosbuvir (NS5B polymerase inhibitor) (LDV/SOF) has been reported to obtain SVR12 rates of $94.2 \%{ }^{10}$.

Real world data are necessary to support clinical research results and to confirm treatment choices. This is because the patient populations in clinical studies are highly selectively determined and may not be heterogenous. The aim of this study was to present the real-world data which evaluated the clinical efficacy and reliability of $\operatorname{PrOD} \pm \mathrm{RBV}$ and
$\mathrm{LDV} / \mathrm{SOF} \pm \mathrm{RBV}$ treatment regimens in an $\mathrm{HCV}$ genotype 1 patient group living in our region.

\section{MATERIAL AND METHODS}

\section{Study population}

This study was an observational cohort study which evaluated antiviral treatment in $\mathrm{HCV}$ infected patients in routine clinical practice. The study recorded the data of consecutive $\mathrm{HCV}$ genotype $1 \mathrm{a}$ and $1 \mathrm{~b}$ patients aged $>18$ years who were treated with $\mathrm{PrOD} \pm \mathrm{RBV}$ or $\mathrm{LDV} / \mathrm{SOF} \pm$ RBV in the single-center study of the Gastroenterology Clinic of Cumhuriyet University between June 2016 and October 2017. Exclusion criteria were acute HCV infection or co-infection of hepatitis A, B, D or human immunodeficiency virus (HIV). Approval for the study was approved by the local ethical committee (Cumhuriyet University 2017-10/23).

\section{Data collection}

A record was made of demographic and clinical data of the patients, adverse events (AEs), and pre and post-treatment laboratory test results and virological data. Liver cirrhosis diagnosis of the patients was based on clinical findings, ultrasound findings consistent with cirrhosis, and histological findings (METAVIR F4). The liver decompensation sign was defined as Child-Pugh score $\mathrm{B}$ or $\mathrm{C}$, ascites, encephalopathy and esophageal varices. HCV RNA levels were tested using the real-time polymerase chain reaction assay (COBAS AmpliPrep/ COBAS TaqMan system; Roche Molecular Systems Inc., Branchburg, NJ, USA). Measurements were taken at baseline, at 4, 12, and 24 weeks of treatment and at 12 weeks post-treatment (SVR12). The lower limit of determination for HCV RNA was 15 IU/Ml. Virologic response was defined as HCV RNA not determined at 4 weeks (rapid viral response; RVR), at end of treatment (EOT) and at 12 weeks posttreatment (SVR12). Virologic failure was defined as HCV RNA determined at any time throughout treatment or the follow-up period, up to 12 weeks post-treatment. AEs which occurred from the first administration of treatment up to 12 weeks posttreatment were recorded in detail. Anemia was defined as hemoglobin level $<10 \mathrm{~g} / \mathrm{dL}$. 


\section{Treatment}

The treatment regimens (including RBV use) and durations were selected according to the preference of the insurance company of the patient and the approval of the researchers. When determining the treatment regimen, particular attention was paid to drug interactions. The treatment regimens of PrOD (ombitasvir: $25 \mathrm{mg}$, paritaprevir: $150 \mathrm{mg}$, ritonavir: $100 \mathrm{mg}$ once per day and dasabuvir: $250 \mathrm{mg}$ twice per day) and LDV/SOF (ledipasvir: $90 \mathrm{mg}$ and sofosbuvir: $400 \mathrm{mg}$ once per day) were administered orally at standard doses. The RBV dose was $1200 \mathrm{mg}$ for patients with bodyweight $\geq$ $75 \mathrm{~kg}$ and $1000 \mathrm{mg}$ for those $<75 \mathrm{~kg}$ and each dose was split as 2 doses per day. With the approval of the researchers, PrOD + RBV was given to $\mathrm{HCV}$ genotype 1a treatment-naive, non-cirrhotic patients for 12 weeks and PrOD was given to genotype $1 \mathrm{~b}$ treatment-naive, non-cirrhotic patients for 12 weeks. HCV genotype 1a, treatment-naive ChildPugh Class A cirrhotic patients received PrOD + RBV for 24 weeks and genotype $1 \mathrm{~b}$ treatmentnaive Child-Pugh Class A cirrhotic patients received PrOD for 12 weeks, or HCV genotype 1a and $1 \mathrm{~b}$, treatment-naive, cirrhotic patients received $\mathrm{LDV} / \mathrm{SOF}+\mathrm{RBV}$ for 12 weeks or HCV genotype $1 \mathrm{a}$ and $1 \mathrm{~b}$, treatment-naive, cirrhotic patients received $\mathrm{LDV} / \mathrm{SOF}$ for 24 weeks.

HCV genotype 1a, treatment-experienced (Pegileinterferon [PEG-IFN] + RBV \pm telaprevir [TVR] / boceprevir[BOC]) non-cirrhotic patients received PrOD + RBV for 12 weeks and those with genotype $1 \mathrm{~b}$ received PrOD for 12 weeks. HCV genotype $1 \mathrm{a}$, and $1 \mathrm{~b}$, treatment-experienced, noncirrhotic patients received LDV/SOF +RBV for 12 weeks or LDV/SOF for 24 weeks. HCV genotype 1a, treatment-experienced, Child-Pugh Class A cirrhotic patients received PrOD + RBV for 24 weeks and genotype $1 \mathrm{~b}$, treatment-experienced, Child-Pugh Class A cirrhotic patients received PrOD for 12 weeks, or all genotype $1 \mathrm{a}$ and $1 \mathrm{~b}$, treatment-experienced, cirrhotic patients received $\mathrm{LDV} / \mathrm{SOF}+\mathrm{RBV}$ for 12 weeks or all genotype 1a and $1 \mathrm{~b}$, treatment-experienced, cirrhotic patients received LDV/SOF for 24 weeks.

\section{Statistical analysis}

All statistical analyses were performed using SPSS version 22.0 software (Statistical Package for the Social Sciences, Chicago, Illinois, USA). In the evaluation of the data, the Chi-square test was used in $2 \times 2$ sets and multi-cell sets. A value of $\mathrm{p}<0.05$ was accepted as statistically significant.

\section{RESULTS \\ Patient population}

The demographic and clinical characteristics of the $81 \mathrm{HCV}$ patients in the study are shown in Table 1. The $81 \mathrm{HCV}$ patients comprised 35 (43.2\%) males and $46(56.8 \%)$ females with a mean age of 62 years. A total of $41(50.6 \%)$ patients were aged $\geq 65$ years with $\mathrm{BMI} \geq 28 \mathrm{~kg} / \mathrm{m}^{2}$. Similar to the $\mathrm{HCV}$ genotype seen in Turkey, the majority of the patients in the study were genotype $1 \mathrm{~b}$, with $12.3 \%$ determined as genotype $1 \mathrm{a}$ and $87.7 \%$ as genotype $1 b$. Of the total 81 patients in the study, $43(53.1 \%)$ were treatment-experienced and of those, the majority (n:41, 95.3\%) had received PEG-IFN + RBV. The other 2 (4.7\%) patients had used firstgeneration protease inhibitors (PI) combinations. Pre-treatment, $54(67.7 \%)$ patients were noncirrhotic, 18 (22.2\%) were compensated cirrhotic and $9(11.1 \%)$ were decompensated cirrhotic. 
Table 1. Baseline patient demographics and characteristics

\begin{tabular}{|c|c|}
\hline Variables & $\mathrm{n}=81$ \\
\hline Sex, male, $\mathrm{n}(\%)$ & $35(43.2 \%)$ \\
\hline Age, (years, mean $\pm \mathrm{SD}$ ) & $62.4 \pm 12.2$ \\
\hline BMI, $\left(\mathrm{kg} / \mathrm{m}^{2}\right.$, mean $\left.\pm \mathrm{SD}\right)$ & $28 \pm 5$ \\
\hline \multicolumn{2}{|l|}{ Comorbidities, n (\%) } \\
\hline Diabetes & $22(27.2 \%)$ \\
\hline Hypertension & $19(23.5 \%)$ \\
\hline Coronary artery disease & $16(19.8 \%)$ \\
\hline Chronic renal disease & $5(6.2 \%)$ \\
\hline \multicolumn{2}{|l|}{ HCV genotype, n (\%) } \\
\hline $1 \mathrm{a}$ & $10(12.3 \%)$ \\
\hline $1 b$ & $71(87.7 \%)$ \\
\hline \multicolumn{2}{|l|}{ Treatment history, n (\%) } \\
\hline Naive & $38(46.9 \%)$ \\
\hline Experienced & $43(53.1 \%)$ \\
\hline \multicolumn{2}{|l|}{ Treatment-experienced, n (\%) } \\
\hline PEG-IFN $2 a+R B V$ & $25(58.1 \%)$ \\
\hline PEG-IFN 2b+RBV & $16(37.2 \%)$ \\
\hline TVR/BOC-INF+RBV & $2(4.7 \%)$ \\
\hline \multicolumn{2}{|l|}{$\mathrm{HCV}$ antiviral treatment history, $\mathrm{n}(\%)$} \\
\hline Null-responders & $6(14 \%)$ \\
\hline Partial responders & $3(3.7 \%)$ \\
\hline Relapsers & $32(74.4 \%)$ \\
\hline Discontinued due to side effects & $2(2,5)$ \\
\hline \multicolumn{2}{|l|}{ Disease severity, $\mathrm{n}(\%)$} \\
\hline No cirrhosis & $54(66.7 \%)$ \\
\hline Cirrhosis & $18(22.2 \%)$ \\
\hline Decompensated cirrhosis & $9(11.1 \%)$ \\
\hline \multicolumn{2}{|l|}{ Therapeutic regimen, $\mathrm{n}(\%)$} \\
\hline PrOD & $50(61.7 \%)$ \\
\hline PrOD + RBV & $6(7.4 \%)$ \\
\hline $\mathrm{SOF} / \mathrm{LDV}$ & $10(12.4 \%)$ \\
\hline $\mathrm{SOF} / \mathrm{LDV}+\mathrm{RBV}$ & $15(18.5 \%)$ \\
\hline \multicolumn{2}{|l|}{ SVR12, n (\%) } \\
\hline Yes & $79(96.4 \%)$ \\
\hline No & $1(1.2 \%)$ \\
\hline Relaps & $1(1.2 \%)$ \\
\hline \multicolumn{2}{|l|}{ Treatment duration, $\mathrm{n}(\%)$} \\
\hline 12 weeks & $74(91.4 \%)$ \\
\hline 24 weeks & $7(8.6 \%)$ \\
\hline
\end{tabular}

BMI - body mass index; HCV - hepatitis C virus; PEG-INF - Pegile-interferon; RBV - ribavirin; TVP/BOC telaprevir/boceprevir; PrOD - paritaprevir, ritonavir, ombitasvir, dasabuvir; SOF/LDV - sofosbuvir, ledipasvir; SVR sustained virologic response.

\section{Clinical effectiveness}

Of the total 81 patients, $50(61.7 \%)$ received $\mathrm{PrOD}$, $6(7.4 \%)$ PrOD + RBV, $10(12.4 \%)$ SOF/LDV and $15(18.5 \%) \mathrm{SOF} / \mathrm{LDV}+\mathrm{RBV}$ treatment regimens. The duration of treatment was 12 weeks in 74 (91.4\%) patients and 24 weeks in 7 (8.6\%). SVR12 response was obtained in $79(96.4 \%)$ patients and could not be obtained in $2(2.4 \%)$. In respect of the different treatment regimens, SVR12 response was obtained in $55(98.2 \%)$ of the patients receiving PrOD \pm RBV and in $24(96 \%)$ of those receiving $\mathrm{SOF} / \mathrm{LDV} \pm \mathrm{RBV}$. No statistically significant difference was determined between the treatment regimens in respect of SVR12 response $(p=0.273)$. SVR12 was obtained in all the treatment-naive patients, irrespective of whether they were cirrhotic or non-cirrhotic. Of the $2 \mathrm{HCV}$ genotype 1 patients who did not reach SVR12, virologic failure was 
observed in one and virologic relapse in the other. The patient with virologic failure was genotype $1 \mathrm{~b}$, treatment-experienced (PEG-IFN + RBV) and was later non-cirrhotic with relapse. The treatment regimen of PrOD was given for 12 weeks but SVR12 could not be obtained. The other patient with virologic relapse was genotype $1 \mathrm{~b}$, treatmentexperienced (PEG-IFN + RBV) and was nullresponder to treatment and decompensated cirrhotic. For 12 weeks the LDV/SOF + RBV treatment regimen was administered, but following treatment virologic relapse was observed in the 3rd week. The laboratory test values are shown in Table 2. The mean HCV RNA level was $1.61 \mathrm{log}$ $\mathrm{IU} / \mathrm{mL}$. Of the laboratory tests, the mean alanine aminotransferase (ALT) and aspartate aminotransferase (AST) levels were determined to be elevated and all other values were within the normal ranges.

Table 2. Baseline laboratory values.

\begin{tabular}{ll}
\hline Variables & $\mathrm{n}=81$ \\
\hline HCV RNA $(\log \mathrm{IU} / \mathrm{mL})$ & $1.61 \pm 1.99$ \\
White cell count, $(\mathrm{x} \mathrm{10} / \mathrm{L})$ & $3.9 \pm 1.7$ \\
Hemoglobin, g/dL & $13.6 \pm 2.1$ \\
Platelets, $(\mathrm{x} \mathrm{10} / \mathrm{L})$ & $172.3 \pm 79.7$ \\
ALT, U/L & $52.4 \pm 41.7$ \\
AST, U/L & $53.3 \pm 40.2$ \\
Total biluribin, mg/dL & $0.96 \pm 0.5$ \\
Albumin, g/dL & $3.8 \pm 0.6$ \\
Creatinine, mg/dL & $1.1 \pm 0.7$ \\
INR & $1.1 \pm 0.2$ \\
\hline
\end{tabular}

Data expressed as mean \pm SD. HVC RNA, hepatitis C virus RNA; ALT, alanine aminotransferase; AST, aspartate aminotransferase; INR, international normalized ratio.

\section{Safety}

AEs were reported in $46(56.8 \%)$ of the patients in this study (Table 3). Treatment was not stopped because of side-effects in any case and all the patients completed the treatments. The most common of the side-effects reported in $\geq 5$ patients were pruritus, fatigue, headache, nausea, insomnia, myalgia and anemia. No statistically significant difference was determined between the $\operatorname{PrOD} \pm$ $\mathrm{RBV}$ and $\mathrm{LDV} / \mathrm{SOF} \pm \mathrm{RBV}$ regimens in respect of AEs $(p=0.174)$. The most common AEs were pruritus in $18(22.2 \%)$ patients, fatigue in $17(21 \%)$ and headache in $16(19.8 \%)$. When evaluated according to the treatment regimen, the AEs reported in those receiving PrOD were headache in $13(23.2 \%)$, pruritus in $12(21.4 \%)$, and fatigue in $12(21.4 \%)$ and in those receiving LDV/SOF treatment, the most common AEs were pruritus in $6(24 \%)$ and fatigue in $5(20 \%)$. Anemia was observed in 6 (28.6\%) of the 21 patients using RBV and it did not cause termination of treatment in any case.

Table 3. Adverse events of patients

\begin{tabular}{|c|c|c|c|c|c|c|c|}
\hline & \multicolumn{2}{|c|}{$\begin{array}{l}\text { All patients } \\
\quad(\mathrm{n}=81)\end{array}$} & \multicolumn{2}{|c|}{$\begin{array}{c}\mathrm{PrOD} \pm \mathrm{RBV} \\
(\mathrm{n}=56)\end{array}$} & \multicolumn{2}{|c|}{$\begin{array}{c}\mathrm{LDV} / \mathrm{SOF} \pm \mathrm{RBV} \\
(\mathrm{n}=25)\end{array}$} & \multirow[t]{2}{*}{$\begin{array}{c}\mathrm{p} \\
\text { Values }\end{array}$} \\
\hline & $\mathrm{n}$ & $\%$ & $\mathrm{n}$ & $\%$ & $\mathrm{n}$ & $\%$ & \\
\hline $\begin{array}{l}\text { Advers } \\
\text { reactions }\end{array}$ & 46 & $56.8 \%$ & 29 & $51.8 \%$ & 17 & $68 \%$ & 0.174 \\
\hline Pruritis & 18 & $22.2 \%$ & 12 & $21.4 \%$ & 6 & $24 \%$ & 0.797 \\
\hline Fatigue & 17 & $21 \%$ & 12 & $21.4 \%$ & 5 & $20 \%$ & 0.805 \\
\hline Headache & 16 & $19.8 \%$ & 13 & $23.2 \%$ & 3 & $12 \%$ & 0.242 \\
\hline Nausea & 12 & $14.8 \%$ & 9 & $16.1 \%$ & 3 & $12 \%$ & 0.634 \\
\hline İ̀somnia & 11 & $13.6 \%$ & 8 & $14.3 \%$ & 3 & $12 \%$ & 0.781 \\
\hline Myalgia & 7 & $8.6 \%$ & 4 & $7.1 \%$ & 3 & $12 \%$ & 0.472 \\
\hline Anemia & 7 & $8.6 \%$ & 3 & $5,3 \%$ & 3 & $12 \%$ & 0.427 \\
\hline Rash & 3 & $3.7 \%$ & 2 & $3.6 \%$ & 1 & $4 \%$ & 0.925 \\
\hline
\end{tabular}

PrOD, paritaprevir, ritonavir, ombitasvir, dasabuvir; RBV, ribavirin; SOF/LDV, sofosbuvir, ledipasvir. 


\section{DISCUSSION}

As patient selection is applied according to various criteria in Phase III studies that have been conducted on second-generation direct-acting antivirals (DAAs) in chronic hepatitis C patients, the efficacy and safety of the drugs has been lower than real-world data ${ }^{11}$. The aim of this real-world cohort study was to evaluate in a single-center study the efficacy and safety of the secondgeneration DAA treatment regimens of PrOD \pm $\mathrm{RBV}$ and $\mathrm{SOF} / \mathrm{LDV} \pm \mathrm{RBV}$, which have started to be used in clinical practice, on chronic $\mathrm{HCV}$ genotype 1 patients living in our region.

Both in Turkey and throughout the world, the most common genotype is 1 , and the dominant subtype of this is genotype $1 \mathrm{~b}$. In an extensive prevalence study in Turkey, genotype 1 was found to be the most common in patients with HCV infection and the majority $(92.1 \%)$ were sub-genotype $1 b^{12}$. Similar to this reported prevalence in Turkey, the patients in the current study were all genotype 1 and the majority $(87.7 \%)$ were sub-genotype $1 b$. Most of the patients were treatment-experienced and were patients with relapse following PEG-IFN treatment. SVR12 reponse was obtained at the rate of $96.4 \%$ from the HCV genotype 1 patients in this study, including those with cirrhosis or previous treatment failure. When the patients were evaluated according to the treatment regimen, SVR12 was obtained at the rate of $98.2 \%$ in those receiving $\mathrm{PrOD} \pm \mathrm{RBV}$ and at $96 \%$ in SOF/LDV $\pm \mathrm{RBV}$. No statistically significant difference was determined between the treatment regimens in respect of SVR12 rates and both were observed to have reached a high rate.

Clinical studies made of drugs which have newly come into use include selected patients and they are followed up closely. Real-world data are obtained from heterogenous patient groups in clinical practice. To confirm the findings of clinical research, evaluate the efficacy and safety of drugs and guide treatment decisions, real-world data are necessary.

The discovery of second-generation DAAs was made with several Phase III studies. Of these, the PEARL -III and PEARL-IV studies were conducted on HCV genotype $1 \mathrm{a}$ and genotype $1 \mathrm{~b}$ infected patients treated with $\mathrm{PrOD} \pm \mathrm{RBV}$, and SVR12 response was obtained in $90.2 \%-99.5 \%$. There was no significant difference between genotypes $1 \mathrm{a}$ and $1 \mathrm{~b}$ in respect of SVR12 response although virologic failure was determined at a higher rate in the genotype 1a group without RBV compared to the group with RBV ${ }^{13}$. In the TURQUOISE-II study, SVR12 response was obtained at the rate of $86.7 \%-100 \%$ in $\mathrm{HCV}$ genotype $1 \mathrm{a}$ and $1 \mathrm{~b}$ infected cirrhotic patients treated with $\mathrm{PrOD} \pm \mathrm{RBV}$. However, the SVR12 rate was determined to be slightly lower in the HCV genotype 1a, null-responder cirrhotic patients with 12 weeks treatment of PrOD + RBV ${ }^{14}$. In the ION 1 and 2 studies, the SVR12 rates were reported as $99 \%$ and $94 \%$, respectively in treatment-naive and treatment-experienced $\mathrm{HCV}$ genotype 1 patients treated with $\mathrm{SOF} / \mathrm{LDV} \pm \mathrm{RBV}^{15}{ }^{16}$. As seen in many Phase III studies of second-generation DAAs, high SVR12 rates have been obtained at similar rates for both $\mathrm{PrOD} \pm \mathrm{RBV}$ and $\mathrm{SOF} / \mathrm{LDV}$ \pm RBV. In the current study, SVR12 responses were obtained at high rates similar to those of Phase III studies.

In many regions of the world, real-world data has started to be presented related to the secondgeneration DAA treatment regimens of $\operatorname{PrOD} \pm$ $\mathrm{RBV}$ and $\mathrm{SOF} / \mathrm{LDV} \pm \mathrm{RBV}$. A study in Germany conducted with real-world data obtained SVR12 responses at the rate of $96 \%-97 \%$ for $\mathrm{HCV}$ genotype 1 patients treated with $\mathrm{PrOD} \pm \mathrm{RBV}{ }^{17}$. Chan et al ${ }^{18}$ reported an SVR12 response rate of $95.1 \%$ in Hong Kong HCV genotype 1b patients treated with PrOD $\pm \mathrm{RBV}$. According to the realworld data of Shin et al, SVR12 response of $92.2 \%$ was obtained with treatment of SOF/LDV in HCV genotype 1 patients ${ }^{19}$. In the real-world data of heterogenous patient groups of a study by Backus et al, SVR12 responses were obtained of $90 \%$ 91.4\% with SOF/LDV $\pm \mathrm{RBV}$, and $85.8 \%-95.1 \%$ with $\mathrm{PrOD} \pm \mathrm{RBV}^{20}$. According to the real-world data of a study in Spain, SVR12 responses in HCV genotype 1 infections were $96.8 \%$ with $\mathrm{PrOD} \pm$ $\mathrm{RBV}$ and $95.8 \%$ with $\mathrm{SOF} / \mathrm{LDV} \pm \mathrm{RBV}^{21}$. In a study by Ionnou et al of elderly ( $\geq 65$ years) HCV genotype 1 infection patients, SVR12 response was reported as $92.2 \%-94.2 \%$ in patients treated with PrOD and SOF/LDV ${ }^{22}$. In the current study of realworld data in a Turkish population, high rates of SVR12 response were obtained of $96 \%-98.2 \%$ in HCV genotype 1 infected patients, and these results were seen to be consistent with the real-world data from different geographic regions.

The rate of second-generation DAA virologic failure in the current study was low, which was similar to the results of Phase III studies and realworld data ${ }^{21,22}$. SVR12 was not obtained in $1.8 \%$ $4 \%$ of the HCV infected genotype 1 patients of the current study. This was due to virologic failure in 1 patient and virologic relapse in 1 patient. The patient with virologic failure was non-cirrhotic, genotype $1 \mathrm{~b}$, PEG-IFN + RBV treatmentexperienced and received 12 weeks of PrOD treatment. 
The other patient with virologic relapse was decompensated cirrhotic, genotype $1 \mathrm{~b}$, nullresponder to PEG-IFN +RBV treatment and received $L D V / S O F+R B V$ treatment for 12 weeks. Relapse developed in this patient in the $3 \mathrm{rd}$ week after treatment. However, SVR12 response was obtained in all treatment-naive patients, irrespective of whether they were cirrhotic or noncirrhotic. Therefore, care is necessary in treatmentexperienced patients in respect of the choice of treatment and duration.

Hepatitis $\mathrm{C}$ infection is now a treatable infection for many cases, unlike HBV and HIV, but requires the use of multiple agents as resistance can develop against a single agent. A high rate of replication and virus heterogeneity cause DAA resistance in patients. The treatment regimen, baseline viral load, host genetic factors and treatment duration are important in resistance to DAA used in HCV infection. However, despite the high rates of SVR12 with DAA treatment, in some patients it cannot be obtained. Baseline resistance-associated substitutions (RASs) in NS5A, NS5B and NS3 have a minimal effect on patient response to PrOD and SOF/LDV therapy. The most common RASs in HCV infection are K24R, L31M, Q30H/R, and $\mathrm{Y} 93 \mathrm{H} / \mathrm{N}$ in genotype $1 \mathrm{a}$, and $\mathrm{Y} 93 \mathrm{H} / \mathrm{N}, \mathrm{L} 31 \mathrm{M}$ and $\mathrm{K} 24 \mathrm{R}$ in genotype $1 \mathrm{~b}$. As resistance tests were not examined in our laboratory, the resistant mutant strains could not be determined in the 2 patients where SVR 12 could not be obtained ${ }^{23,24}$.

Although the current study group was heterogenous, safety and tolerability was found to be excellent in both groups. AEs were reported in $56.8 \%$ of the current study patients. The most common AEs in both regimens were pruritus, fatigue and headache. In patients receiving $\mathrm{PrOD} \pm$ $\mathrm{RBV}$, the most frequent AEs were headache, pruritus and fatigue and in those receiving $\mathrm{LDV} / \mathrm{SOF} \pm \mathrm{RBV}$, pruritus and fatigue. No statistically significant difference was determined between PrOD $\pm \mathrm{RBV}$ and $\mathrm{LDV} / \mathrm{SOF} \pm \mathrm{RBV}$ in respect of AEs. Previous studies have reported treatment termination at a rate of $12.7 \%-13 \%$ in HCV genotype 1 patients who used PEG-IFN alpha $2 a$ and $2 b$ before second-generation DAA ${ }^{25}$. The compatibility with patients of this new secondgeneration DAA is extremely high and the rate of early cessation of treatment is very low at $0.3 \%-1 \%$ 26 , 27 . In the current study, treatment was not terminated early because of side effects in any case. The compatibility of this treatment with the patients was excellent.

In a previous Phase III study of HCV genotype 1 infected cirrhotic patients treated with PrOD \pm
RBV, side-effects were reported in $91.8 \%$, the most common being fatigue, headache, nausea and pruritus. Treatment could not be completed by $2.1 \%$ of the patients because of the development of side-effects ${ }^{26}$. The AEs seen in previous extensive Phase III studies have been at an extremely high rate. In these studies, side-effects were reported at 73.4\%-87.5\% in HCV genotype 1 infected patients treated with $\mathrm{PrOD} \pm \mathrm{RBV}$, most commonly fatigue, headache and nausea. In those studies, treatment could not be completed by $0.6 \%$ of the patients because of the development of side-effects ${ }^{26}$. In the ION 3 study, AEs in genotype 1 patients treated with $\mathrm{SOF} / \mathrm{LDV} \pm \mathrm{RBV}$ were $74 \%-88 \%$. In this study the most common AEs were fatigue, headache and nausea ${ }^{27}$. Fewer AEs have been reported in real-world data than in Phase III studies and there are slightly lower rates of terminating treatment. According to real-world data in a study in Latin America, the incidence of side-effects associated with $\mathrm{PrOD} \pm \mathrm{RBV}$ treatment of $\mathrm{HCV}$ genotype 1 patients was $62 \%$ and the most frequently seen side-effects were fatigue and pruritus ${ }^{28}$. In a study by Terrault et al ${ }^{29}$ of genotype 1 patients, AEs were reported at $63 \%$ in those treated with $\mathrm{PrOD} \pm \mathrm{RBV}$, and at $85 \%$ in those treated with $\mathrm{SOF} / \mathrm{LDV} \pm \mathrm{RBV}$. The most common side-effects were reported to be fatigue, headache and nausea. In both Phase III studies and real-world data, headache, pruritus and fatigue are the most commonly seen AEs with the use of both treatment regimens. However, the rates of AEs in Phase III studies are higher than those of real-world data. In the current study, the rate of AEs was similar to that of previous real-world data and lower than findings in Phase III studies.

However in patients whose HCV-RNA is negative three months after tretament; follow-up $\mathrm{HCV}$ RNAs should also be requested at 24th and 48th weeks after treatment.

Limitations of this study can be said to be that the total numbers of patients and the treatment groups were low and heterogenous. Nevertheless, the realworld data obtained with close monitoring of the patients and recording of the data increased the efficacy and reliability of the study.

In conclusion, a high rate of SVR12 response was obtained and excellent tolerability was seen in the real-world data of chronic $\mathrm{HCV}$ infected genotype 1 patients in our region, which were similar results to the findings of Phase III studies. Moreover, AEs were determined at a lower rate than in Phase III studies. With the use of second-generation DAA, higher rates of tolerability and SVR12 response were obtained in the $\mathrm{HCV}$ infected genotype 1 
patients of this study, compared to patients previously applied with a PEG-IFN-based regimen. The efficacy and tolerability of second-generation

\section{REFERENCES}

1. Lingala S, Ghany MG. Natural History of Hepatitis C. Gastroenterol Clin North Am 2015; 44: 717-34.

2. Gower E, Estes C, Blach S, Razavi-Shearer K, Razavi H. Global epidemiology and genotype distribution of the hepatitis $\mathrm{C}$ virus infection. $\mathrm{J}$ Hepatol 2014; 61: 45-57.

3. Tozun N, Ozdogan O, Cakaloglu, et al. Seroprevalence of hepatitis $\mathrm{B}$ and $\mathrm{C}$ virus infections and risk factors in Turkey: a fieldwork TURHEP study. Clin Microbiol Infect 2015;21(11):1020-26.

4. Messina JP, Humphreys I, Flaxman A, et al. Global distribution and prevalence of hepatitis $\mathrm{C}$ virus genotypes. Hepatology 2015; 61: 77-87.

5. Gürbüz Y, Tülek NE, Tütüncü EE, et al. Evaluation of Dual Therapy in Real Life Setting in Treatment-Naïve Turkish Patients with HCV Infection: A Multicenter, Retrospective Study, Balkan Medikal J 2016; 33: 18-26.

6. Backus LI, Boothroyd DB, Philips BR, et al. A sustained virologic response reduces risk of allcause mortality in patients with hepatitis C. Clin Gastroenterol Hepatol 2011; 9: 509-16.

7. McHutchison JG, Lawitz EJ, Shiffman ML, et al. IDEAL Study Team. Peginterferon alfa-2b or alfa-2a with ribavirin for treatment of hepatitis $\mathrm{C}$ infection. N Engl J Med, 2009; 361: 580-93.

8. Lawitz EJ, Membreno FE. Response-guided therapy in patients with genotype 1 hepatitis $\mathrm{C}$ virus: current status and future prospects. J Gastroenterol Hepatol 2014; 29: 1574-8.

9. Ahmed H, Abushouk AI, Menshawya A, et al. Safety and Efficacy of Ombitasvir/ Paritaprevir/ Ritonavir and Dasabuvir with or without Ribavirin for Treatment of Hepatitis C Virus Genotype 1: A Systematic Review and Metaanalysis. Clin Drug Investig 2017; 37: 1009-23.

10. Flisiak R, Łucejko M, Mazur W, et al. Effectiveness and safety of ledipasvir /sofosbuvir \pm ribavirin in the treatment of $\mathrm{HCV}$ infection: The real-world HARVEST study. Adv Med Sci 2017; 62: 387-92.

11. Tao T, Jiang X, Chen Y, Song Y._Efficacy and Safety of Ledipasvir/Sofosbuvir with and without Ribavirin in Patients with Chronic Hepatitis C
DAA regimens for genotype 1 patients were determined to be extremely high in the real world.

Virus Genotype 1 Infection: a meta-analysis. Int J Infect Dis 2017; 55: 56-71.

12. Gürbüz Y, Tülek NE, Tobacci EE, et al. Evaluation of Dual Therapy in Real Life Setting in Treatment-Naïve Turkish Patients with HCV Infection: A Multicenter, Retrospective Study. Balkan Med. J, 2016; 33: 18-26.

13. Ferenci P, Bernstein D, Lalezari J, et al. PEARLIII Study; PEARL-IV Study. ABT-450/rombitasvir and dasabuvir with or without ribavirin for HCV. N Engl J Med, 2014; 370: 1983-92.

14. Poordad F, Hezode C, Trinh R, et al._ABT-450/rombitasvir and dasabuvir with ribavirin for hepatitis C with cirrhosis. N Engl J Med, 2014; 370: 1973-82.

15. Afdhal N, Zeuzem S, Kwo P, et al._ION-1 Investigators. Ledipasvir and sofosbuvir for untreated $\mathrm{HCV}$ genotype 1 infection. N Engl J Med 2014; 370: 1889-98.

16. Afdhal N, Reddy KR, Nelson DR, Lawitz E, Gordon SC, Schiff E, et al_ION-2 Investigators. Ledipasvir and sofosbuvir for previously treated HCV genotype 1 infection.N Engl J Med 2014; 370: 1483-93.

17. Welzel TM, Hinrichsen H, Sarrazin C, et al, Realworld experience with the all-oral, interferon-free regimen of ombitasvir/paritaprevir/ritonavir and dasabuvir for the treatment of chronic hepatitis $\mathrm{C}$ virus infection in the German Hepatitis C Registry. J Viral Hepat 2017; 24: 840-49.

18. Chan HL, Tsang OT, Hui YT, et al._Real-life efficacy and safety of paritaprevir/ritonavir, ombitasvir, and dasabuvir in chronic hepatitis $\mathrm{C}$ patients in Hong Kong. J Gastroenterol Hepatol 2017; 32: 1230-33.

19. Shin HP, Burman B, Kozarek RA, et al._RealWorld Single-Center Experience with Sofosbuvir-Based Regimens for the Treatment of Chronic Hepatitis C Genotype 1 Patients. Gut Liver 2017; 11: 711-20.

20. Backus LI, Belperio PS, Shahoumian TA, et al. Comparative effectiveness of ledipasvir/ sofosbuvir \pm ribavirin vs. ombitasvir/ paritaprevir /ritonavir/dasabuvir \pm ribavirin in 6961 genotype 1 patients treated in routine medical practice. Aliment Pharmacol Ther, 2016; 44: 400-10.

21. Calleja JL, Crespo J, Rincón D, et al. Spanish Group for the Study of the Use of Direct-acting Drugs Hepatitis C Collaborating Group. Effectiveness, safety and clinical outcomes of 
direct-acting antiviral therapy in HCV genotype 1 infection: Results from a Spanish real-world cohort. J Hepatol 2017; 66: 1138-48.

22. Su F, Best LA, Green PK, Berry K, Ioannou GN. Direct-acting antivirals are effective for chronic hepatitis $\mathrm{C}$ treatment in elderly patients: a realworld study of 17487 patients. Eur J Gastroenterol Hepatol 2017; 29: 686-93.

23. Rong L, Dahari H, Ribeiro RM, Perelson AS. Rapid emergence of protease inhibitor resistance in hepatitis C virus. Sci Transl Med 2010; 2: 3032.

24. Sarrazin C, Dvory-Sobol H, Svarovskaia ES, et al. Prevalence of Resistance-Associated Substitutions in HCV NS5A, NS5B, or NS3 and Outcomes of Treatment With Ledipasvir and Sofosbuvir. Gastroenterology 2016; 151: 501-12.

25. Miyase S, Haraoka K, Ouchida Y, Morishita Y, Fujiyama S. Randomized trial of peginterferon $\alpha-2$ a plus ribavirin versus peginterferon $\alpha-2 b$ plus ribavirin for chronic hepatitis $\mathrm{C}$ in
Japanese patients. J Gastroenterol 2012; 47: 1014-21.

26. Feld JJ, Kowdley KV, Coakley E, et al. Treatment of HCV with ABT-450/r ombitasvir and dasabuvir with ribavirin. N Engl J Med 2014; 370: 1594-603.

27. Alqahtani SA, Afdhal N, Zeuzem S, et al. Safety and tolerability of ledipasvir/sofosbuvir with and without ribavirin in patients with chronic hepatitis $\mathrm{C}$ virus genotype 1 infection: Analysis of phase III ION trials Hepatology 2015; 62: 2530.

28. Mendizabal M, Haddad L, Gallardo PE, et al. Ombitasvir/paritaprevir/ritonavir/ dasabuvir \pm ribavirin is safe and effective in HCV-infected patients in a real-life cohort from Latin America. J Med Virol, 2017; 89: 1590-96.

29. Terrault NA, Zeuzem S, Bisceglie D, et al._HCVTARGET Study Group_Effectiveness of Ledipasvir-Sofosbuvir Combination in Patients With Hepatitis C Virus Infection and Factors Associated With Sustained Virologic Response. Gastroenterology 2016; 151: 1131-40. 